\title{
Blast-Induced Hearing Loss
}

\author{
Sung Il Cho \\ Department of Otolaryngology-Head and Neck Surgery, Chosun University College of Medicine, Gwangju, Korea
}

\section{폭발성 난청}

\section{조 성 일}

조선대학교 의학전문대학원 이비인후과학교실

Received March 29, 2013

Accepted May 8, 2013

Address for correspondence

Sung Il Cho, MD, PhD

Department of Otolaryngology-Head and Neck Surgery,

Chosun University College of

Medicine, 365 Pilmun-daero,

Dong-gu, Gwangju 501-717, Korea

Tel +82-62-220-3207

Fax +82-62-225-2702

E-mail chosi@chosun.ac.kr
Blast injuries are increasing worldwide from combat and explosions in heavy industry. Primary blast injury is direct injury due to the high pressure effects and pressure differentials of the blast wave itself. Alternating overpressure and underpressure imposed upon tissues of heterogenous densities, particularly air-filled organs. The ear is the first affected organ to primary blast injury because it is the body's most sensitive pressure transducer. Otologic blast injury and tympanic membrane perforation have traditionally been used as a predictor, or biomarker, of occult serious primary blast injury. Hearing loss and tinnitus are the most common ear symptoms. This review details the otologic consequences of blast exposure.

Korean J Otorhinolaryngol-Head Neck Surg 2013;56:251-5

Key Words Blast injury $\cdot$ Ear $\cdot$ Hearing loss.

\section{서 론}

최근 폭발물의 사용은 증가 추세에 있으며 이로 인한 손상 은 기존에 다른 원인으로 인한 손상과 다르게 나타난다. 폭발 의 효과는 주변으로 빠르게 확장하는 고압 가스로 인한 손상 과 파편에 의한 물리적 손상 등을 일으킬 수 있으며 청각기는 공기로 채워져 있는 특성상 폭발로 인한 압력에 가장 취약한 기관이다. 폭발음은 주로 폭발 장치나 대포, 총기 등에 의해 음 속보다 빠른 속도의 과중 압력(overpressure)을 야기하여 손 상을 일으키게 된다.1) 고막부터 내이를 포함한 중추 청각기 에 이르기까지 모든 청각 기관이 손상될 수 있으며 이러한 결 과로 일시적 혹은 영구적 난청을 유발하게 된다. ${ }^{2)}$ 본 종설에 서는 지금까지 알려진 폭발성 난청의 기전을 정리하여 이해 를 돕고 폭발로 인한 내이 및 중추 청각기 손상으로 발생하 는 영구적 난청의 예방 및 치료를 위한 연구에 도움이 되고자 한다.

\section{폭발로 인한 손상의 기전}

폭발이 일어나게 되면 그 주변으로 즉시 고압의 가스들이 팽 창하면서 주변 대기의 공기를 압축시켜 고압의 파-(overpressure wave)를 만들게 된다. 이러한 고압파의 가장 바깥쪽 부분이 폭풍파(blast wave)로 알려진 충격파(shock wave)로서 작용 하게 되고 이는 대상 물체에 대하여 파괴와 충격을 나타내게 된다. 폭풍파(blast wave)는 중심부로부터 3000 8000 m/sec 의 속도로 주변으로 퍼져나가며 거리와 시간이 경과함에 따라 압력과 속도가 약해지게 된다. 이와 같은 과중 압력(overpressure)은 폭발 즉시 발생하며 예리한 양압파(sharp positive wave) 의 형태로 기록되게 된다. 폐쇄된 공간의 경우 고압파(overpressure wave)가 벽 등에 반사되어 그 진폭과 노출 시간을 크게 하기 때문에 개방된 공간보다 건물이나 자동차 안 같은 폐쇄된 공간에서 더 큰 진폭의 고압파(overpressure wave)를 관찰할 수 있으며 이로 인해 더 심한 손상이 신체에 나타나게 된다. ${ }^{3)}$ 폭풍파(blast wave) 뒤에 폭발에 의해 발생하는 고열의 공기 는 폭발로 인한 바람(blast wind)을 만들게 된다(Fig. 1). ${ }^{4}$ 이 


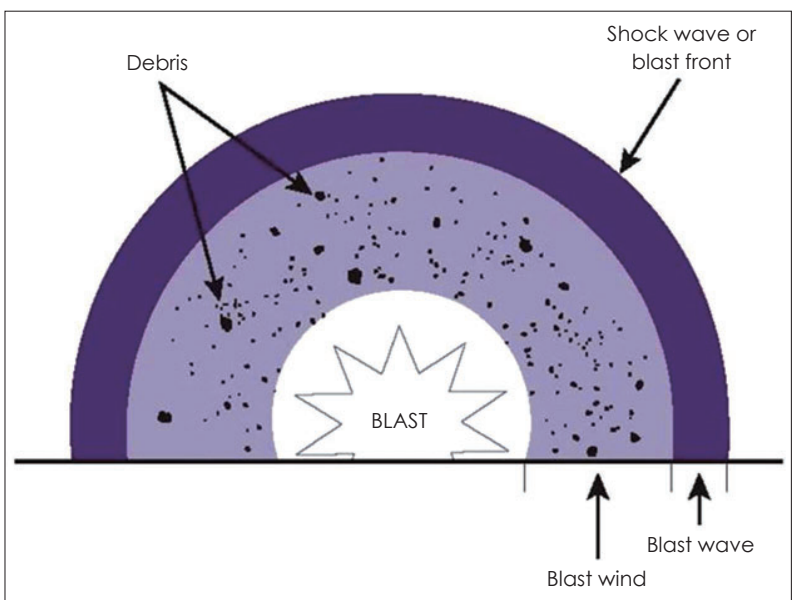

Fig. 1. Components of a blast.

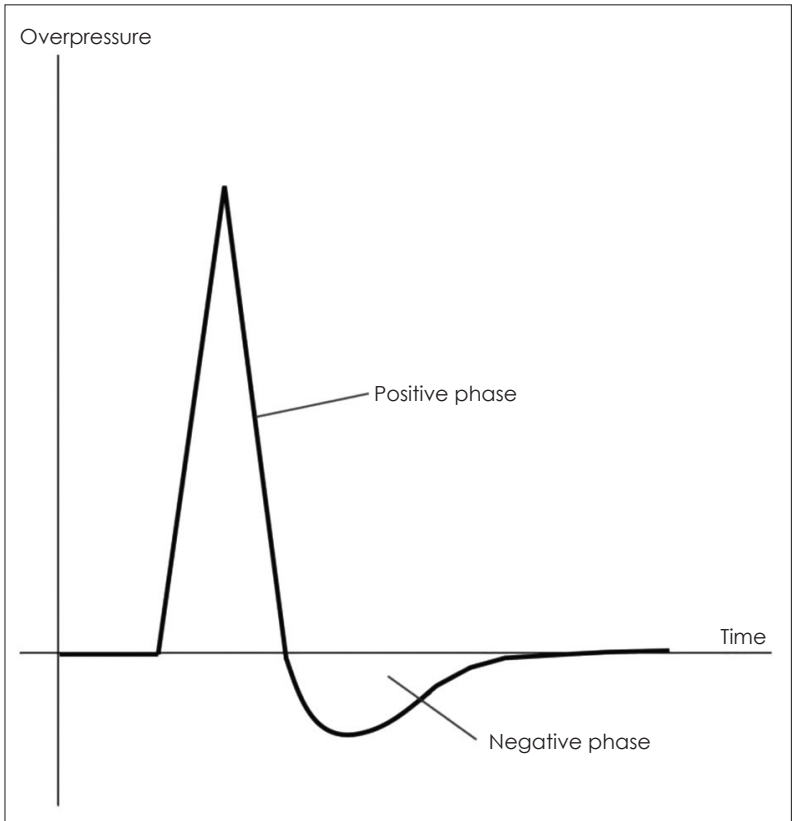

Fig. 2. Graph showing a blast wave in an open environment.

로 인해 신체가 전위되며 주변 구조물에 부딪혀 물리적 손상 을 일으키게 된다. 이러한 고압의 파가 지나가게 되면 그 뒤의 공기는 진공 상태가 형성되며 이로 인해 음압의 파-underpressure wave)를 형성하게 된다. 이러한 음압은 고압의 부분과 비교해서 약 3 배 정도 지속되며 대상 물체에 대한 충격은 훨 씬 약하다. ${ }^{5)}$ 폭발로 인해 발생하는 고압의 파와 음압의 파는 Friedlander curve를 만들게 되며 이를 측정하게 되면 폭발 의 크기를 측정할 수 있다(Fig. 2). ${ }^{6}$ 폭풍파(blast wave)는 두 가지의 에너지 형태로 체내에 흡수되게 된다. 하나는 파형의 움직이는 방향과 동일하게 전달되는 종축 압력(longitudinal pressure)으로 공기-조직 접합면(air-tissue interface)에 미세 혈관 손상 및 조직 파괴 등을 일으킨다. 다른 하나는 전단파 (shear wave)로서 횡축파(transverse wave)를 일으켜 조직의
뒤틀림을 발생시킴으로서 조직의 분열을 일으킨다. 이러한 이유로 폭발로 인한 1차 손상은 주로 귀, 폐 그리고 대장 같은 가스가 포함된 기관이 가장 쉽게 손상받는다. 반면에 단단한 장 기(solid organ)의 경우 상대적으로 영향을 적게 받게 된다.

\section{폭발로 인한 손상의 분류}

폭발로 인한 손상은 4가지로 분류된다. 1차 손상은 폭발로 인한 고압 충격파(blast wave)에 신체가 접촉되어 발생하는 손 상으로 주로 귀, 폐나 내장 같은 공기를 포함한 기관이 가장 많 이 손상받는다. 2차 손상은 폭발로 인한 파편들에 의한 물리 적인 손상이며 3차 손상은 폭발로 인한 바람(blast wind)에 의 해 신체가 날리면서 주변 물체에 부딪혀 발생하는 손상으로 주로 땅에 떨어지거나 주변 물체에 부딪혀 발생하게 된다. 4 차 손상은 화상이나 방사선 노출, 기타 주변 구조물의 붕괴에 의한 외상 등을 모두 포함한다. ${ }^{8)}$ 이 중 청각기의 손상은 1 차 손 상이 가장 흔하며 그 중에서도 중이나 내이의 구조물이 가장 많이 손상받는다.

\section{귀에 대한 폭발 손상 (Blast Injury to the Ear)}

가장 흔한 증상은 난청, 이명, 이통 그리고 어지럼이다. 폭발 손상을 받은 환자 중 35 54\%에서 영구 난청이 발생하였다고 보고되고 있다. ${ }^{910)}$

\section{고 막}

폭발로 인한 고압력(overpressure)은 고막을 내측으로 전위 시키며 그 압력이 클 경우에 천공을 유발하게 된다. $5 \mathrm{psi}$ 의 압 력 이상에서 고막 손상이 나타나며 $15 \mathrm{psi}$ 의 압력에서는 약 $50 \%$ 의 손상을 일으킬 수 있다. ${ }^{11)}$ 손상은 고실내 출혈부터 전 천공 까지 압력의 세기에 따라 매우 다양하게 나타날 수 있다. Kronenberg 등 ${ }^{12)}$ 이 폭발에 노출된 210귀를 대상으로 한 보고에 따르면 대부분의 천공은 주로 하부에 발생하였으며 고막의 이완부에는 발생하지 않았다. 자연 치유율은 $73.8 \%$ 로 보고 했으며 대부분 3 개월 이내에 회복되었다.

\section{중 이}

이소골 연쇄의 손상이 발생할 수 있으며 보통 $85 \mathrm{psi}$ 이상 의 압력에 노출될 때 발생할 수 있다. ${ }^{2)}$ 추골침골 관절의 단절 (disruption)과 추골병의 내측 전위, 침골등골 관절의 단절 등이 가장 흔하게 발생한다. ${ }^{13)}$ 고막 천공이나 이소골 손상으로 인해 전음성, 혼합성 난청이 나타날 수 있으며 상피 조직들이 
고막 천공을 통해 중이 내로 침습되면 추후 진주종 형성의 가 능성도 있다. ${ }^{14)}$

\section{내 이}

폭발음에 노출 후 일시적인 고도의 청각 역치(temporary hearing threshold) 변동 후 시간이 지나면서 청력의 회복이 관찰 된다. 대부분의 회복은 수시간 이내에 일어나며 수일에서 수 주에 걸쳐 회복이 진행될 수 있다. 하지만 일부 환자의 경우 영 구적인 난청과 이명이 남을 수 있다. ${ }^{15)}$ 드물지만 현훈도 발생 할 수 있으며 양성 돌발성 체위성 현훈, 외림프 누공, 난형낭 이나 구형낭의 손상이 그 원인으로 생각되고 있다. ${ }^{16)}$ 하지만, 현훈의 경우 내이의 손상보다는 뇌를 포함한 중추 신경계의 손상으로 발생하는 경우가 많아 이에 대한 적절한 평가가 필 요하다. ${ }^{17)}$ 폭발에 노출된 환자들에서 전정기능 검사를 시행한 결과 말초성 병변 뿐만 아니라 중추성 병변을 시사하는 검사 소견이 관찰되었고 이는 뇌 손상에 의한 중추 전정계의 병변도 어지럼을 일으키는 데 관여함을 알 수 있다. ${ }^{18)}$

\section{폭발로 인한 난청의 기전}

폭발로 인한 감각신경성 난청의 기전은 코르티 기관의 망상 층(reticular lamina)의 외상성 변화가 전해질 투과성의 변화를 야기해 발생한다고 알려져 있고 망상층(reticular lamina)이 재생되면 난청이나 이명이 완화된다고 보고되었으며 영구 난 청의 경우 비가역적인 유모 세포 손상과 함께 코르티 기관의 물리적 손상이 관찰되었다. ${ }^{19-21)}$ Hamernik 등 ${ }^{19)}$ 은 친칠라에 $160 \mathrm{~dB}$ SPL 크기의 충격성 잡음(impulse noise)을 100회 노 출시킨 후 폭발파(blast wave)는 두 가지 기전에 의해 와우 내 손상을 유발한다고 보고하였다. 심한 기계적 손상으로 인해 코 르티 기관내의 감각 세포와 지지 세포들이 기저막으로부터 분 리되었으며 감각 세포의 손상 및 소실과 외유모 세포 섬모의 분열(disruption) 및 망상층(reticular lamina)에서 헨센 세포 (Hensen cell)의 분열(disruption)을 보고하였다. 또한, 와우 내 손상 후 이차적인 반흔 형성이 관찰되었으며 대식세포가 관찰되는 등 외상에 의한 손상 후 염증 반응을 다른 원인으로 제시하였다.

그 후 Roberto 등 ${ }^{20)}$ 은 돼지와 양을 대상으로 178 209 dB $\mathrm{SPL}$ 의 폭발음에 노출시킨 후 코르티 기관의 손상 및 고막 천 공, 이소골 손상 등을 확인하였다. 쥐(rat)를 이용한 실험에서 는 고실계(scala tympani)의 외림프액에 출혈을 관찰할 수 있 었으며 이는 뇌 손상에 의한 지주막하 출혈이 와우 도수관을 통해 외림프액으로 확산되었을 것으로 추정하였다. ${ }^{22)}$ 최근에 는 폭발음에 노출된 쥐(rat)에서 고막 손상과 와우 유모세포의
소실 등이 폭발음의 세기와 노출 시간의 증가에 따라 증가하 는 것이 보고되었다. ${ }^{23)}$

내이 손상의 다른 기전으로 와우 혈류량의 변화가 제시되었 다. Chen 등 ${ }^{24)}$ 이 guinea pig를 대상으로 한 실험에서 폭발에 노출 후 와우 혈류량의 증가를 확인하였으며 이는 3 24시간 이내에 정상으로 회복되었다. 하지만, 혈류량의 변화가 내이 손상에 미치는 정도는 와우 내의 구조적 손상에 비해 그 효과 가 크지 않다고 하였다.

감각신경성 난청의 또 다른 기전은 중추 청각기의 손상이 다. 폭발에 노출 후 해마(hippocampus)에서 청각 리본형 시냅 스(auditory ribbon synapse)의 글루타메이트 세포 외 유출 (glutamate exocytosis)에 필수적인 Otoferin 발현의 저하가 관 찰되었으며 Otoancorin 발현의 증가가 관찰되었는데 이는 청 각 손상 후 보상기전의 하나로 설명하였으며 이명 발현을 설명 할 수 있는 기전으로 제시하였다. 그리고 Cadherin과 Protocadherin 발현이 뇌의 다양한 영역에서 변화가 나타났으며 또 한 해부학적으로 청각 피질의 신경 변성(neurodegeneration) 이 관찰되었는데 이는 노출된 귀의 반대쪽 내측 부위에 현저 하게 발현되어 중추 청각기의 손상이 폭발성 난청에 관여할 수 있음을 제시하였다. ${ }^{25)}$

그 외에 부동 섬모(stereocilia)에서 액틴 필라멘트(actin filament)의 해중합(depolymerization)과 혈관조, 구심 신경 말 단, 지지 세포의 팽창 등이 난청의 기전으로 제시되고 있으며 ${ }^{26)}$ Glutamate 같은 와우 내 청각 신호전달 물질의 과도한 분비, 외유모 세포막의 유동성(fluidity), glucocorticoid 수용체의 역 할 변화, 산화 스트레스 등과의 관련성도 제시되고 있다. ${ }^{27,28)}$

\section{폭발로 인한 전음성 난청의 치료}

고막 천공은 대다수(78 88\%)의 경우 3개월 이내에 치유되 며 그 예후가 좋다. ${ }^{929)}$ 하지만, 치유되지 않는 경우 고막 성형술 을 요하며 추후 진주종이 형성되지 않는지 적어도 2년 동안은 추적 관찰이 요구된다. ${ }^{30)}$ 중이 내 저류가 발생한 경우도 대부 분의 경우 자연 치유가 되며 이소골 손상의 경우 이소골 성형 술을 요한다.

\section{폭발로 인한 감각신경성 난청의 치료}

폭발로 인한 폐나 뇌 같은 다른 장기의 손상에 항산화제 (antioxidant)의 사용이 시도되었다. 친칠라에서 폭발로 인한 폐 손상 후 $\mathrm{N}$-acetylcysteine(NAC)이 염증 반응을 완화시키 는 것이 보고되었고 ${ }^{31)}$ 뇌 손상 후에도 산화 스트레스(oxidative stress)를 완화시켜 염증 반응을 약화시키는 것으로 알려졌 
다. ${ }^{32)} \mathrm{NAC}$ 는 폭발음에 노출된 쥐를 대상으로 실험한 결과 산 화 스트레스를 줄여 청각의 보존과 유모 세포 보존에 효과가 있음이 알려졌다. 특히 노출 후 24시간 이내에 투여될 경우 영 구 난청을 일으키는 생물학적 과정(biological processes)의 시작을 억제할 수 있으므로 항산화제 투여 시간이 중요하다고 하였다. ${ }^{23)} \mathrm{NAC}$ 는 고용량으로 투여됐을 때에도 와우 독성이 없었으나 보호 효과는 고용량에 비해 저용량에서 강하다고 보 고되었다. ${ }^{33)}$ 또 다른 항산화제인 glutathione monoethylester 도 친칠라를 대상으로 한 실험에서 청력과 유모 세포에 대한 보존 효과가 알려지고 있다. ${ }^{34)}$ 항산화제 외에 스테로이드 사용 에 관한 연구가 시도되고 있으며 dexamethasone의 경우 중이 내 국소 투여 후 음향 외상으로부터 보호 효과가 있다고 보고 되고 있다. ${ }^{35)}$ 스테로이드의 사용은 그 효과에 논란이 있지만 금 기 질환이 없는 환자에서 단기간 동안 사용이 권해지고 있다. ${ }^{36}$

\section{결 론}

폭발로 인한 손상은 최근 증가 추세에 있으며 영구적인 난 청을 유발할 수 있다. 하지만 폭발 손상에 관한 기존의 연구 는 주로 폐나 뇌 같은 치명적일 수 있는 장기에 국한된 반면 가장 흔한 손상을 일으키는 청각기에 대한 연구는 아직까지 많지 않은 실정이다. 폭발로 인한 물리적 및 음향 외상은 중 이, 내이, 중추 청각기에 영향을 미칠 수 있으며 중이 질환은 쉽게 치료 될 수 있는 반면 내이나 중추 청각기의 병변은 회 복이 쉽지 않아 예방이 중요하다. 지금까지 보고된 내이와 중 추 청각기에서의 폭발성 난청 기전들은 여전히 논란의 여지가 있으며 영구적 난청을 일으킬 수 있으므로 효과적인 예방과 치료를 위해 추후 더 많은 연구가 필요할 것으로 생각된다.

\section{Acknowledgments}

This study was supported by research funds from Chosun University, 2010.

\section{REFERENCES}

1) Clifford RE, Rogers RA. Impulse noise: theoretical solutions to the quandary of cochlear protection. Ann Otol Rhinol Laryngol 2009; 118(6):417-27.

2) Chandler DW, Edmond CV. Effects of blast overpressure on the ear: case reports. J Am Acad Audiol 1997;8(2):81-8.

3) Garner J, Brett SJ. Mechanisms of injury by explosive devices. Anesthesiol Clin 2007;25(1):147-60, x.

4) Darley DS, Kellman RM. Otologic considerations of blast injury. Disaster Med Public Health Prep 2010;4(2):145-52.

5) Born CT. Blast trauma: the fourth weapon of mass destruction. Scand J Surg 2005;94(4):279-85.

6) Radford P, Patel HD, Hamilton N, Collins M, Dryden S. Tympanic membrane rupture in the survivors of the July 7, 2005, London bombings. Otolaryngol Head Neck Surg 2011;145(5):806-12.

7) Ritenour AE, Baskin TW. Primary blast injury: update on diagnosis and treatment. Crit Care Med 2008;36(7 Suppl):S311-7.

8) Sasser SM, Sattin RW, Hunt RC, Krohmer J. Blast lung injury. Prehosp Emerg Care 2006;10(2):165-72.

9) Chait RH, Casler J, Zajtchuk JT. Blast injury of the ear: historical perspective. Ann Otol Rhinol Laryngol Suppl 1989;140:9-12.

10) Hull JB. Blast: injury patterns and their recording. J Audiov Media Med 1992;15(3):121-7.

11) Hirsch FG. Effects of overpressure on the ear--a review. Ann N Y Acad Sci 1968;152(1):147-62.

12) Kronenberg J, Ben-Shoshan J, Wolf M. Perforated tympanic membrane after blast injury. Am J Otol 1993;14(1):92-4.

13) Horrocks CL. Blast injuries: biophysics, pathophysiology and management principles. J R Army Med Corps 2001;147(1):28-40.

14) Kronenberg J, Ben-Shoshan J, Modan M, Leventon G. Blast injury and cholesteatoma. Am J Otol 1988;9(2):127-30.

15) Mrena R, Pääkkönen R, Bäck L, Pirvola U, Ylikoski J. Otologic consequences of blast exposure: a Finnish case study of a shopping mall bomb explosion. Acta Otolaryngol 2004;124(8):946-52.

16) Cohen JT, Ziv G, Bloom J, Zikk D, Rapoport Y, Himmelfarb MZ. Blast injury of the ear in a confined space explosion: auditory and vestibular evaluation. Isr Med Assoc J 2002;4(7):559-62.

17) Casler JD, Chait RH, Zajtchuk JT. Treatment of blast injury to the ear. Ann Otol Rhinol Laryngol Suppl 1989;140:13-6.

18) Scherer MR, Burrows H, Pinto R, Littlefield P, French LM, Tarbett $\mathrm{AK}$, et al. Evidence of central and peripheral vestibular pathology in blast-related traumatic brain injury. Otol Neurotol 2011;32(4): 571-80.

19) Hamernik RP, Turrentine G, Roberto M, Salvi R, Henderson D. Anatomical correlates of impulse noise-induced mechanical damage in the cochlea. Hear Res 1984;13(3):229-47.

20) Roberto M, Hamernik RP, Turrentine GA. Damage of the auditory system associated with acute blast trauma. Ann Otol Rhinol Laryngol Suppl 1989;140:23-34.

21) Patterson JH Jr, Hamernik RP. Blast overpressure induced structural and functional changes in the auditory system. Toxicology 1997; 121(1):29-40.

22) Hoffer ME, Balaban C. Neurotologic consequences of blast injury. International Brain Injury Association. NeuroTrauma Letter 05. Available from: URL: http://www.internationalbrain.org/articles/ neurotologic-consequences-of-blast-injury/.

23) Ewert DL, Lu J, Li W, Du X, Floyd R, Kopke R. Antioxidant treatment reduces blast-induced cochlear damage and hearing loss. Hear Res 2012;285(1-2):29-39.

24) Chen W, Wang J, Chen J, Chen J, Chen Z. Relationship between changes in the cochlear blood flow and disorder of hearing function induced by blast injury in guinea pigs. Int J Clin Exp Pathol 2013; 6(3):375-84.

25) Valiyaveettil M, Alamneh Y, Miller SA, Hammamieh R, Wang Y, Arun $\mathrm{P}$, et al. Preliminary studies on differential expression of auditory functional genes in the brain after repeated blast exposures. J Rehabil Res Dev 2012;49(7):1153-62.

26) Fausti SA, Wilmington DJ, Gallun FJ, Myers PJ, Henry JA. Auditory and vestibular dysfunction associated with blast-related traumatic brain injury. J Rehabil Res Dev 2009;46(6):797-810.

27) Chen GD, Zhao HB. Effects of intense noise exposure on the outer hair cell plasma membrane fluidity. Hear Res 2007;226(1-2):14-21.

28) Tahera Y, Meltser I, Johansson P, Bian Z, Stierna P, Hansson AC, et al. NF-kappaB mediated glucocorticoid response in the inner ear after acoustic trauma. J Neurosci Res 2006;83(6):1066-76.

29) Garth RJ. Blast injury of the ear: an overview and guide to management. Injury 1995;26(6):363-6.

30) Cripps NP, Glover MA, Guy RJ. The pathophysiology of primary blast injury and its implications for treatment. Part II: The auditory structures and abdomen. J R Nav Med Serv 1999;85(1):13-24. 
31) Chavko M, Adeeb S, Ahlers ST, McCarron RM. Attenuation of pulmonary inflammation after exposure to blast overpressure by N-acetylcysteine amide. Shock 2009;32(3):325-31.

32) Chen G, Shi J, Hu Z, Hang C. Inhibitory effect on cerebral inflammatory response following traumatic brain injury in rats: a potential neuroprotective mechanism of $\mathrm{N}$-acetylcysteine. Mediators Inflamm 2008;2008:716458.

33) Duan M, Qiu J, Laurell G, Olofsson A, Counter SA, Borg E. Dose and time-dependent protection of the antioxidant N-L-acetylcysteine against impulse noise trauma. Hear Res 2004;192(1-2):1-9.
34) Henderson D, McFadden SL, Liu CC, Hight N, Zheng XY. The role of antioxidants in protection from impulse noise. Ann N Y Acad Sci 1999; 884:368-80.

35) Chi FL, Yang MQ, Zhou YD, Wang B. Therapeutic efficacy of topical application of dexamethasone to the round window niche after acoustic trauma caused by intensive impulse noise in guinea pigs. $\mathrm{J}$ Laryngol Otol 2011;125(7):673-85.

36) Cope D, Bova R. Steroids in otolaryngology. Laryngoscope 2008;118 (9):1556-60. 